\title{
Effect of Pre-Theoretic Intuitions Quiz Constructivist Strategy on Student's Achievement in Environment-Related Concepts in Biology.
}

\author{
OluyemiAkinleye, Ogundiwin ${ }^{1}$, Adebare Idowu, Adegoke ${ }^{2}$, \\ Olayemi Aderokun Asaaju ${ }^{3}$ \\ 123, Department of Teacher Education,University of Ibadan, Ibadan, Nigeria.
}

\begin{abstract}
One strategy proved in literature to have exposed students to a higher thinking order to recognise assumptions, evaluate controversies, and scrutinise inferences is needed in alleviating the problem of low achievement in the teaching of environmental concept in biology. This study, therefore, determined the effects of Pre-theoretic intuition quiz constructivist strategy on students' achievement in environment-related concepts in Biology; it also investigated effects of cognitive styles and gender.

The pretest-posttest, control group, quasi-experimental design with $2 \times 2 \times 2$ factorial matrix was adopted.451 students from four local government areas of Nigeria were used for the study. Instruments used for data collection were: Teachers Instructional Guides for treatments and control groups; Students' Environmental Achievement Test $(r=0.80)$, Cognitive Style Test (test-retest $r=0.81)$ and Assessment Sheet for the research assistants. Three null hypotheses were tested at 0.05 level of significance. Data collected were analyzed using Analysis of Covariance (ANCOVA).

Treatment had significant effect on students' Post-test achievement score $(F(1,438)=209.620 ; P<0.05)$. Pretheoretic intuition quiz improved students' achievement than conventional strategy in environment-related concepts in Biology.

It is, recommended that teachers, curriculum developers and textbook writers should adopt the instructional strategy for enhancing students' achievement in environmental education in Biology.
\end{abstract}

Keywords: Pre-Theoretic Intuition Quiz, Biology, Environmental education, Student's achievement, Conventional strategy, Cognitive style and Gender.

\section{Introduction}

Developing countries such as Nigeria in 1980 started experiencing serious and complex environmental problems which include over-population, pollution, unchecked industrialization, over-use of natural resources, flooding, erosion, solid waste disposal problem, desertification and drought. The biosphere on which all organisms depend for survival are deteriorating rapidly as a result of the activities of human beings (Ajitoni,2009) The Ogunpa flood disaster that occurred in Ibadan in 1980 due to the incident of the dumping of waste on streams, ditches and rivers brought environmental degradation into limelight.

Knapp \& Benton (2006) noted that education is supposed to communicate effectively to the public about the nature and magnitude of the environmental problems whereby sustainable use of environmental resources is emphasized in environmental education. Adegbile (2002) was of the opinion that teachers who wish to impart knowledge including the magnitude of these environmental problems must employ metacognitive (ability to monitor, use and control thinking skills) teaching strategies. The Environmental concepts are present in the West African Secondary School Certificate Examinations Syllabus.

Over the years, experts have continued to draw attention to the grave consequences of constant decline in the performance of our secondary school students in science subjects especially in public examinations such as National Examinations Council and West African Secondary School Certificate Examinations (Ogunleye, 2002). This is corroborated by Abimbola (2013) that the performance level for science subjects did not show any significant rise for a twenty-year period between 1991 to 2011 and confirmed that candidates performance in Biology over those years never rose above 50\% perhaps because non science students used to register for Biology as a core science subject. The analysis of Senior School Certificate Examinations' result in Table 1. below made available from the West African Examinations Council (WAEC) statistics unit on enrolment of students and their performance in biology revealed the enormity of this problem. 
Effect of Pre-Theoretic Intuitions Quiz Constructivist Strategy on Student's Achievement ....

Table 1.: Statistics For Entries And Result For May/June Wassce Biology For 2000-2013

\begin{tabular}{|l|l|l|l|l|}
\hline \multirow{2}{*}{ Year } & Total Entry & Total sat & $\begin{array}{c}\text { Credit } \\
\mathbf{1 - 6}\end{array}$ & Passes \\
& No of Candidates. & No of Candidates & No of Candidates & $\begin{array}{c}\text { \% } \\
\text { Candidates }\end{array}$ \\
\cline { 2 - 5 } & & & & 31.52 \\
\hline 2002 & $1,240,163$ & 882,119 & 278,112 & 44.15 \\
\hline 2003 & $1,006,831$ & 909,101 & 392,249 & 24.69 \\
\hline 2004 & $1,005,553$ & $1,027,938$ & 253,487 & 35.04 \\
\hline 2005 & $1,080,162$ & $1,072,607$ & 375,850 & 48.60 \\
\hline 2007 & $1,170,522$ & $1,152,045$ & 559,854 & 33.37 \\
\hline 2008 & $1,270,137$ & $1,238,163$ & 413,211 & 33.94 \\
\hline 2009 & $1,292,910$ & $1,259,964$ & 427,644 & 33.87 \\
\hline 2010 & $1,372,567$ & $1,340,206$ & 453,928 & 33.90 \\
\hline 2011 & $1,331,381$ & $1,300,418$ & 427,644 & 579 \\
\hline 2012 & $1,540,141$ & $1,505,199$ & 579,432 & 38.50 \\
\hline 2013 & $1,695,878$ & $1,672,224$ & 649,156 & 38.82 \\
\hline
\end{tabular}

Source: Statistics Section, West African Examination Council (WAEC) National Office, Onipanu, Lagos, Nigeria.

From table 1., the number of percentage credit passes and above in Biology continues to fall below $50 \%$ for the period of eleven years reviewed, although grade 7 and 8 are considered to be Passes but these are not good enough for candidates gaining admission into tertiary institutions.

Despite all efforts to improve students' performance in Biology, it has been observed, unfortunately, that the educational system is to a great extent not achieving its predetermined goals and objectives due to high failure in public examinations such as the Senior School Certificate Examinations (Ndioho,2007). The percentage passes for the year 2002 to 2013 are not good enough especially for candidates that want to study biological sciences and biology based courses or for any candidate that may include biology as one of the relevant five subjects, passed at credit level in order to be admitted into any higher institutions in Nigeria as seen in the admission rate between 1995/1996 academic session and 2007/2008 academic session has been slow in improving as stated by Jekayinfa, Yusuf, Yahaya \& Yusuf,( 2010) and supported by Abimbola (2013) who concluded that the percentage of candidate admitted did not reach 20 percent during this period, except1998/1999 academic session when it was 23.09 percent.

The West African Examinations Council (WAEC) (2003, 2002a), Chief Examiners' report stressed that candidates showed poor grasp of the concepts of ecology contributed a lot to the poor performance of the candidates. Some did not attempt questions raised on ecology concepts and those who attempted the questions performed badly. Also, According to Chief Examiners' Reports in Nigeria (2002b), most candidates did well in items that require listing the correct alternative (knowledge level Bloom taxonomy) but a few made spelling errors and could not spell some environmental concepts terminologies. Most candidates could not state the roles of decomposers in the ecosystem but few did well in this question.

The trend occurs in the Chief Examiners' Reports in Nigeria (2003) where few candidates performed better in questions on adaptive features of climbing animals for example presence of prehensile tails, opposable digits, sticky/adhesive discs on fingers etc. and generally did not score well on this sub-number. In stating uses of water to rainforest organisms, some candidate wrote on uses of water to man and wrote 'drinking, washing and cooking' rather than maintaining body temperature, essential for plant turgidity, necessary for

The trend continues in the Chief Examiners' Reports in Nigeria (2004). Many candidates could not state three precautions necessary to get accurate result in the experiment to measure transpiration. A few candidates wrote that the amount of water in the soil rather than in the atmosphere affects the rate of

In the Chief Examiners' Reports in Nigeria (2005), it was reported that most candidates merely define the habitat they did not list the various types of habitat or give examples. The same thing applied to the ecological niche; the candidates could not differentiate between defining and writing short notes, some candidates could not state the correct uses of the ecological instrument listed and a few made spelling errors and so lost marks for example Secchi dish instead of secchi disc. Few candidates named dogs and goats as animals found in the savanna region.

Chief Examiners' Reports in Nigeria (2007) indicated that candidates performed fairly on the definition of pollution and pollutants of water. In describing the effects of the named pollutants on aquatic organisms, some candidates wrote on general effects of pollution on the environment. A few candidates who wrote on effects of the pollutants on aquatic organisms did not separate the effects of each pollutant. They lumped the Candidates failed to perform better on items requiring answers on the effects and prevention of Noise Pollution. The same trend occurred in Chief Examiners' Reports in Nigeria (2009) where few candidates were able to answer questions on the flow of Energy through the food chain. 
The same trend occurred in 2010 where candidates failed to explain convincingly the terms; Niche, Population density and Climatic Community. Majority of the candidates that sat for 2010 Biology examination was unable to explain the interaction between abiotic and biotic components of an ecosystem.

In 2011, a lot of candidates find it difficult to state and explain the second law of thermodynamics. There was no difference in the performance of candidates that sat in 2012 from the previous year 2011, Many Candidates in 2012, were unable to explain the term ENDANGERED SPECIES, though many candidates were able to explain conservation decomposition linking their specific examples.

In all these years mentioned, candidates' weaknesses were also found to be in the following areas:

- Inability to identify some illustrated organisms;

- Inability to give correct reasons for identifying labeled parts of illustrated diagrams, and

- Errors in spelling biological terms .

Constructivism, as a learning theory, the roots of which can be found in the works of Piaget and Vygotsky, can be traced back to decades, while the actual application of the theory is relatively new (Richardson, 2003). Active learning strategies obtain their roots from Constructivism. Research shows that good pedagogical practices are more likely when including a constructivist approach as compared to a mere traditional approach to education (Azzarito, 2003; DiEnno \& Hilton (2005); Muller, Sharma \& Reimann, 2006). Cognitive Constructivism is applicable to The Pre Theoretic Intuition Quiz. Cognitive Constructivism according to Fosnot (1996) is the concept that learners actively construct their own knowledge and meaning from their experiences. Knowledge is deemed fluid and in a constant state of change, therefore, student's ability to construct viable knowledge and to adapt and be flexible is highly paramount. The implication of cognitive constructivism, according to Kato and Kammi (2001) is that the child becomes very autonomous and docile, refusing to be governed by reward and punishment. The Pre Theoretic Intuition Quiz obtains its roots from this theory.

While the importance of acquisition and recall of basic knowledge remains important, the development of Pre Theoretic Intuition Quiz has emerged as equally important and the strategy finds balance to facilitate the acquisition of basic knowledge in order to develop and nurture critical thinking in education which is important in the acquisition of great achievement

The principles governing Pre-theoretic Intuition Quiz Strategy identified by its proponents Odom and Barrow, (1995) and Hestenes, (2006) include the following;

(1) An instructor attracts student's attention and activates their background knowledge through the First-tier lower cognitive level quiz thereby reviewing prerequisite knowledge or skills. The feedback should be carefully considered to find out the sub-concept that seem to be abstract, confusing and mixed up.

(2) Teacher asks second-tier quiz items, which are upper cognitive level questions utilized to activate students' thinking before answering the questions. The feedback from student quiz makes it easier to identify students' misconceptions on the sub-concept and to determine whether those misconceptions could be corrected.

(3) Tiers of questions based on the distinction between students' knowledge of outcome and mechanism provide an additional source of information for instructors. They also assess students' knowledge of the subject matter in a pre- post-teaching comparison.

(4) Students move on to study a body of content knowledge that follows in learning sequence. Wood and Gentile (2003), Blair, Schwartz, Biswas and Lewlawong (2007), express the opinion that the conventional method of teaching science is inadequate for effective learning in science.

Researchers have come up with different findings on the effect of gender on learning outcomes. While some found no significant differences based on gender Morribend (2004), Chukwuka (2005), Ogunleye (2002) and Raimi, (2003) individually reported that males perform better than their female counterparts in science subjects. Okeke (2001) and Aremu (2005) also reported significant effect of gender on learning outcomes in favour of the male students.

It has also been suggested that student's cognitive styles mediate learning (Ige, 2001). Most of the differences encountered in students' learning could be described in terms of the different manner in which students perceive and analyze a stimulus configuration.

\section{Statement of the problem}

This study determined the effect that The Pre-Theoretic Intuitions Quiz Constructivist strategy will have on student's achievement in Environmental Education concepts in Primary Basic science. It also determined the gender of the pupils` and their cognitive style will have any effect on the students learning outcomes in Environmental concept in Biology. 
Effect of Pre-Theoretic Intuitions Quiz Constructivist Strategy on Student's Achievement ....

\section{Hypotheses}

The following null hypotheses were tested at 0.05 level of significance.

$\mathrm{HO}_{1}$ : There is no significant main effect of treatment on students' Environmental Education achievement

$\mathrm{HO}_{2}$ : There is no significant main effect of cognitive style on students' Environmental Education achievement

$\mathrm{HO}_{3}$ : There is no significant main effect of gender on students' Environmental Education achievement

\section{Methodology}

\section{Research Design}

This study adopted pretest, posttest, control group, quasi-experimental design. It examined possible effects of the Pre-Theoretic Intuition Quiz, pupils' achievement on selected environmental concepts in Primary basic science.

A 2 X 2 X 2 factorial matrix will be adopted with instructional strategy as treatment manipulated at two levels, gender at two levels (male and female) and cognitive style at two levels (analytical and non-analytical).

\section{Selection of Participants}

Four hundred and fifty one Senior Secondary two (SS II) biology students (189 male and 262 females) participated in the study. The subjects were from nine intact classes used for the study. Nine purposively selected co-educational secondary schools in Ibadan North, Ibadan North East, Ibadan Southeast and Akinyele local government Areas of Oyo State, Nigeria.

The choice of SSII biology students was made because they have been exposed to introductory aspects of pollution and conservation techniques as environmental concepts in junior secondary school basic science and SSI biology which act, as pre-requisites for the study of the chosen concepts.

The selection of schools was based on the following criteria:

- Co-educational schools.

- Availability of experienced biology teachers with at least three years teaching experience.

- Evidence of SSII students of the schools not to have been exposed to the concepts of the study.

- Evidence of SSII students of the schools having been exposed to pre-requisite concepts necessary for the understanding of the concepts of the study in their Junior Secondary Schools.

- Willingness of the required members of staff to participate in the study

\section{Research Instruments}

Five instruments constructed by the researcher were used in this study to collect data.

i Students Environmental Achievement Test (SEAT)

ii Cognitive Style Test (CST)

iii Teachers Instructional Guide (TIG) on Pre-theoretic Intuition Quiz on Environmental Concepts in Biology (TIGPT)

iv Teachers Instructional Guide (TIG) on Modified Conventional Method on Environmental Concepts in Biology (TIGCM)

v Evaluation Sheet for Assessing Teachers Performance on the use of the Strategies (ESAT) on Pre-theoretic Intuition Quiz and Modified Conventional Strategies in Environmental Concepts in Biology.

\section{Students' Environmental Achievement Test (SEAT)}

This instrument was adapted from Biological Concepts Instrument (BCI) type of conceptual assessment created by the "Thinking like a Biologist research group" at Michigan State University. The multiple test items, research-based instrument (available on-line) developed by Klymkowsky, Underwood, \& Garvin-Doxas, (2010), was specifically adapted to measure the students' level of achievement in environmental pollution and conservation in Biology. The instrument is made up of two sections.

Section A - This consisted of the personal data of the subjects containing their gender, name of school, etc

Section B - This consisted of 20 multiple test items of Air, water and land pollution including the conservation techniques. Students will be required to pick the option in line with their views on each item. All questions are in objective form with alternatives A to D. Students are to pick the correct answer out of the alternatives provided. The table of specification for the development of the test is in the Table 3.2. The table is in accordance with Okpala and Onocha (1995) in which the six levels of Bloom taxonomy is reduced to three levels; this is done in this research to show the thinking skills that the research is based upon.

Table 2: Table of Specification on (SEAT)

\begin{tabular}{|l|l|l|l|l|}
\hline Cognitive Level Content & $\begin{array}{l}\text { Remembering } \\
\text { (Knowledge Recall) }\end{array}$ & $\begin{array}{l}\text { Understanding } \\
\text { (Comprehension and } \\
\text { Application) }\end{array}$ & $\begin{array}{l}\text { Thinking Analysis, } \\
\text { Synthesis and Evaluation) } \\
\mathbf{3 5 \%}\end{array}$ & $\begin{array}{l}\text { Total } \\
\mathbf{3 0 \%}\end{array}$ \\
\hline
\end{tabular}


Effect of Pre-Theoretic Intuitions Quiz Constructivist Strategy on Student's Achievement ....

\begin{tabular}{|c|c|c|c|c|c|}
\hline & & & $35 \%$ & & $100 \%$ \\
\hline Air Pollution & (1) & 18, & (3) $, 8,11,19$ & (2) 9,16 & 6 \\
\hline Water pollution & (2) 1,14 & & (2) 2,12, & (1) 20 & 5 \\
\hline Land pollution & (1) & 6 & $(2)$ & (1) 10,13 & 4 \\
\hline Conservation techniques & (2) 4,7 & & $(1)$ & 5,17 & 5 \\
\hline Total & 6 & & 7 & 7 & 20 \\
\hline
\end{tabular}

In the 1950s, Bloom found that most of the test questions developed to assess students' learning required them only to think at the lowest level of learning, the recall of information (Hobgood, Thibault and Walbert, 2005). Today, a considerable amount of attention is given to students' abilities to think critically about what they do. These thinking resources will help foster thinking skills that lead to greater comprehension for all students using the original and revised Bloom's Taxonomy

\section{Validation of SEAT}

This instrument was subjected to face and content validity by giving copies to experts in education, educational evaluation and science education with bias in Biology and Environmental Education. These experts were asked to determine its suitability for the target population in terms of clarity, breath and language. Out of the initial 40 items prepared, only 35 items survived scrutiny. The average difficulty and discriminating indices were determined after the instrument was trial tested on a sample of 30 students in a separate school. The difficulty and discriminating indices range from 0.40 and 0.60 and only 20 items survived scrutiny. The reliability coefficient of 0.80 was obtained using Kuder Richardson (KR.20).

\section{Cognitive Style Test (CST)}

This instrument was in line with that of Sigel's cognitive style Test (1967). The revised edition by Awolola (2009) was adapted in this study. The CST consists of twenty cards numbered 1 to 20. Each card contains three pictures in black and white, two of which could have one thing or the other in common which could go together. The CST was used to classify the students into 'analytic' and 'non-analytic' styles on the basis of their statements regarding the way they perceive the pictures. The students were asked to respond to each set of three pictures by noting how any two of the three pictures in the set go together or are related in any way. The trial test results showed no ambiguities in the instrument with a test-retest reliability value of 0.84 were obtained. A test-retest reliability value of 0.81 was obtained in present study.

\section{Teachers' Instructional Guide on Pre-Theoretic Intuition Quiz Strategy (TIGPT)}

Steps involved in Teachers' Instruction Guide on Pre-theoretic intuition quiz in environmental pollution (TIGPT)

Introduction attracts student's attention and activates their background knowledge through the first tier lower level quiz that reviews prerequisite knowledge or skills.

Presentation involves:

-Teacher asks second-tier higher level quiz to activate students thinking before answering the questions.

-Students think independently between four to six seconds before answering the questions.

-More second-tier upper cognitive level quiz asked generate additional source of information based on answers provided by the students to the quiz.

Evaluation involves:

-Teacher clarifies students view on the concept by assessing students for more critical analysis by allowing students to try out the new concept or skill in class.

-Homework or assignment given for more assessment of the skills developed.

TIGPT was given to two University lecturers in Teacher Education Department to reconstruct some of the guide. The recommendations given were used to reconstruct the guide and the inter-rater reliability was then estimated using Scott'

$\pi$. The inter-rater reliability index obtained was 0.76 .

\section{Teacher's Instructional Guide on Modified Conventional Strategy}

(TIGCS)

Steps involved in conventional strategy in environmental pollution including the conservation techniques.

The main features of the guide are general information which consist of subject, topic, the procedure, the teacher, general objective, contents for each week and specific treatment package for each week. The instructional guide was given to two senior secondary school Biology teachers for review and all their suggestions were incorporated in the guide The recommendations given were used to reconstruct the guide and the inter-rater reliability was then estimated using Scott' $\pi$. The inter-rater reliability index obtained was 0.72 . 


\section{Evaluation Sheet for Assessing Teachers' Performance on the use of the} Strategies (ESAT)

This is the guidelines for evaluating performance of the trained teachers on the effective use of these strategies

(1) Pre-theoretic Intuition Quiz (PRESAT).

(2) Modified Conventional Strategy (MESAT).

\section{Research Procedure for the Study}

The following time schedule will be adopted;

The first week for visitation to schools to be used for the treatment.

The next two (2) weeks for training of research assistants

One (1) week for scrutiny of research assistants to ensure that they are ready to do what they are supposed to do. (During demonstration lesson).

One (1) week for pre-test (Administration of SEAT and CST)

Eight (8) weeks for treatment using the trained research assistants on the listed strategies. These take place simultaneously in all the schools selected.

One (1) week Posttest (Administration of SEAT)

This makes a total of fourteen (14) weeks starting from January 9th, 2014 to April 17th, 2014.

\section{Procedure for Data Analysis}

The data was analyzed using Analysis of Covariance (ANCOVA) of the posttest scores with the pretest scores as the covariates. Multiple classification analysis (Sidak Approach) was used to determine estimated marginal means of different groups.

\section{Results}

The results were interpreted at the 0.05 level of significance

\section{Testing of Hypotheses}

H01: There is no significant main effect of treatment on students' environmental achievement. Table 3 represents the summary of ANCOVA results on subjects' posttest achievement scores.

Table 3: 2 X 2 X 2 ANCOVA of Post-test Achievement Scores of students by Treatment, Cognitive Style and Gender

\begin{tabular}{|l|l|l|l|l|l|l|}
\hline Source & $\begin{array}{l}\text { Type III Df } \\
\text { Sum } \\
\text { Squares }\end{array}$ & $\begin{array}{l}\text { Mean } \\
\text { Square }\end{array}$ & F & Sig. & $\begin{array}{l}\text { Partial Eta } \\
\text { Squared }\end{array}$ \\
\hline Corrected Model & 3512.202 & 12 & 292.684 & 46.196 & .000 & .559 \\
\hline $\begin{array}{l}\text { Intercept } \\
\text { PRE- }\end{array}$ & 4271.069 & 1 & 4271.069 & 674.128 & .000 & .606 \\
\hline $\begin{array}{l}\text { ENVIRONMENTAL } \\
\text { ACHIEVEMENT-TEST }\end{array}$ & & & & & & \\
\hline TREATMENT & 348.605 & 1 & 348.605 & 55.022 & .000 & .112. \\
\hline COGNITIVE-STYLE & 1328.089 & 1 & 1328.089 & 209.620 & $.000 *$ & .489 \\
\hline GENDER & 7.162 & 1 & 7.162 & 1.130 & .288 & .003 \\
\hline Error & 2.386 & 1 & 2.386 & .377 & .540 & .001 \\
\hline Total & 2775.035 & 438 & 6.336 & & & \\
\hline Corrected Total & 67448.000 & 451 & & & & \\
\hline
\end{tabular}

R.Squared $=.559($ Adjusted R. Squared $=.547) \quad *$ Significant at $\mathrm{P}<.05$

Table 3 revealed that treatment had a significant effect on subjects' post-test achievement scores ( $\mathrm{F}(1$, $438)=209.620 ;<.05 ;$ partial eta squared $=.489)$. The effect size of $48.9 \%$ was fair. The hypothesis was therefore rejected. This means that there was a significant difference in the mean achievement scores of subjects exposed to the Pre-Theoretic Intuition Quiz strategy. On the basis of this finding, hypotheses 1 was rejected. To find out the magnitude of the mean scores of the group's performance, Table 4 is presented

Table 4.: Estimated Marginal Means of Posttest Achievement Scores by Treatment and Control Group

\begin{tabular}{|c|c|c|c|c|}
\hline \multirow[b]{2}{*}{ Treatment } & \multirow[b]{2}{*}{ Mean } & \multirow[b]{2}{*}{$\begin{array}{l}\text { Std } \\
\text { Error }\end{array}$} & \multicolumn{2}{|c|}{$95 \%$ Confidence Interval } \\
\hline & & & Lower Bound & Upper Bound \\
\hline Pre- theoretic & 14.296 & .242 & 13.820 & 14.772 \\
\hline Conventional & 8.227 & .200 & 7.833 & 8.621 \\
\hline
\end{tabular}


Table 4 indicated that students in the Pre-Theoretic Intuition Quiz treatment group had the highest adjusted posttest mean achievement scores $(\bar{X}=14.296)$ followed by students in the Modified Conventional strategy group had the lower adjusted mean achievement scores $(\bar{X}=8.227)$.

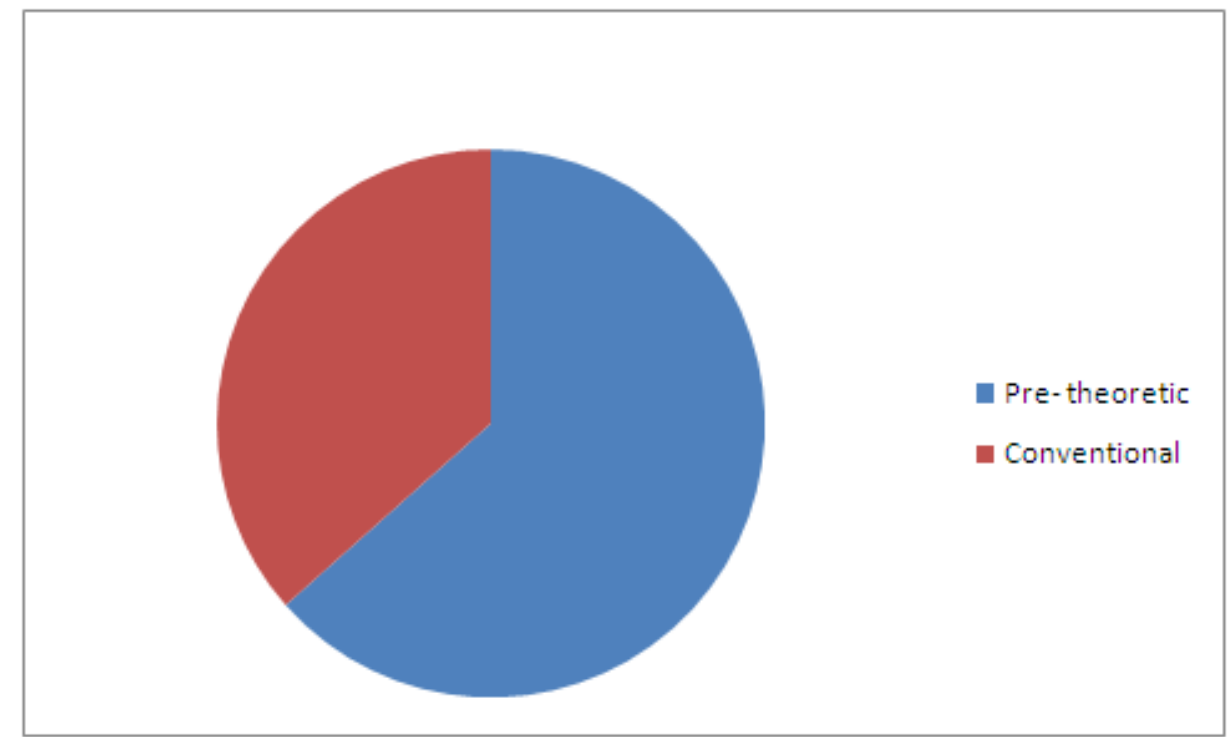

Figure 2: Pie chart showing the Magnitude of Mean scores of Students in Pre-theoretic Intuition Quiz Strategy group and Conventional Strategy group in the achievement Test

The direction of increasing effect of instructional strategy (treatment) on environmental achievement was Modified Conventional strategy < Pre-Theoretic Intuition Quiz.

H02: There is no significant main effect of cognitive style on Pupils' environmental achievement.

Table 3 revealed that cognitive style had no significant effect on the students' achievement $(\mathrm{F}(1,438)=1.130$; $\mathrm{P}<.05$; partial eta squared $=.003)$. The effect size of $.3 \%$ was negligible. Therefore, hypothesis 2 was not rejected.

The magnitude of the mean scores of the group's performance is presented in a bar chart as shown in figure 3 below,

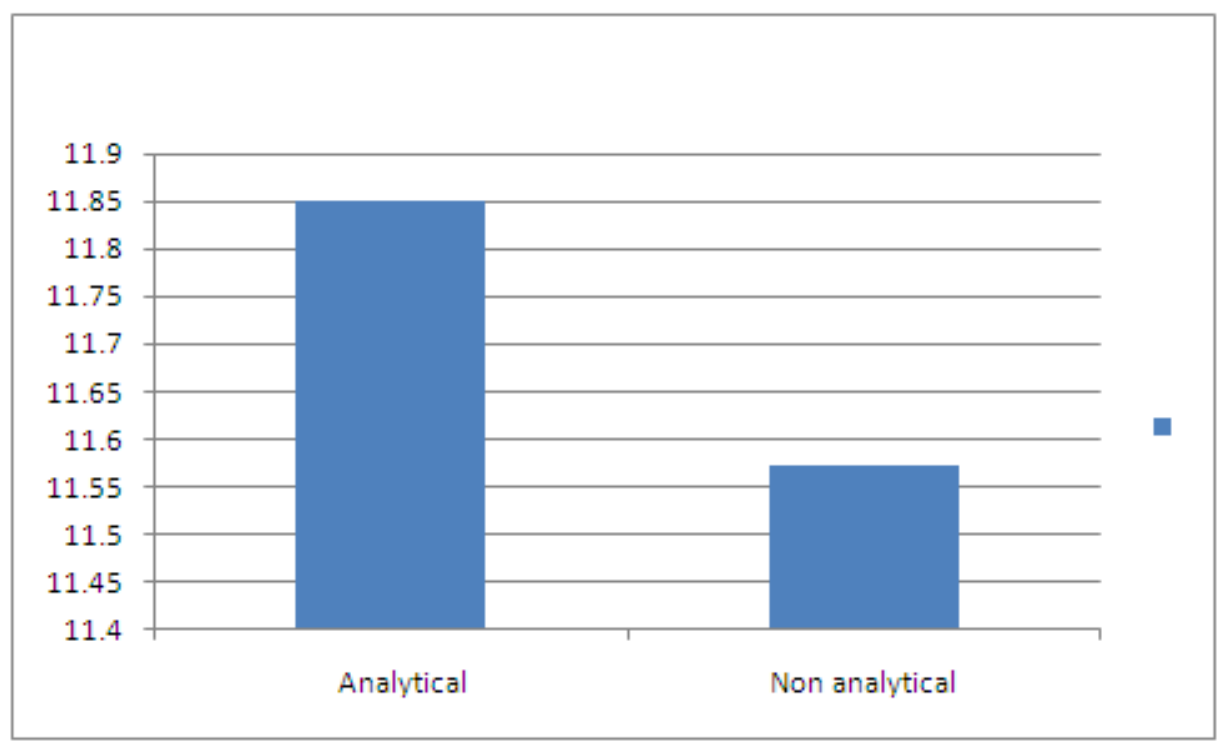

Figure 3: Bar chart showing the Mean scores of Students in Analytical group and Non analytical group in achievement Test 
In Figure 3, Analytical students had higher Mean = 11.851 while the Non analytical students had a lower Mean $=11.574$, but the difference was not significant, therefore cognitive style had no effect on students environmental education achievement.

Ho 3: There is no significant main effect of gender on students' environmental achievement.

Table 3 revealed that gender had no significant effect on students' achievement in environmental pollution. (F $(1,438)=.377 ; \mathrm{p}>0.0 ;$ partial eta squared $=.001)$ The effect size of $0.1 \%$ was negligible. Therefore, hypothesis 3 was not rejected.

The magnitude of the mean scores of the group's performance is presented in a bar chart as shown in figure 4 below;

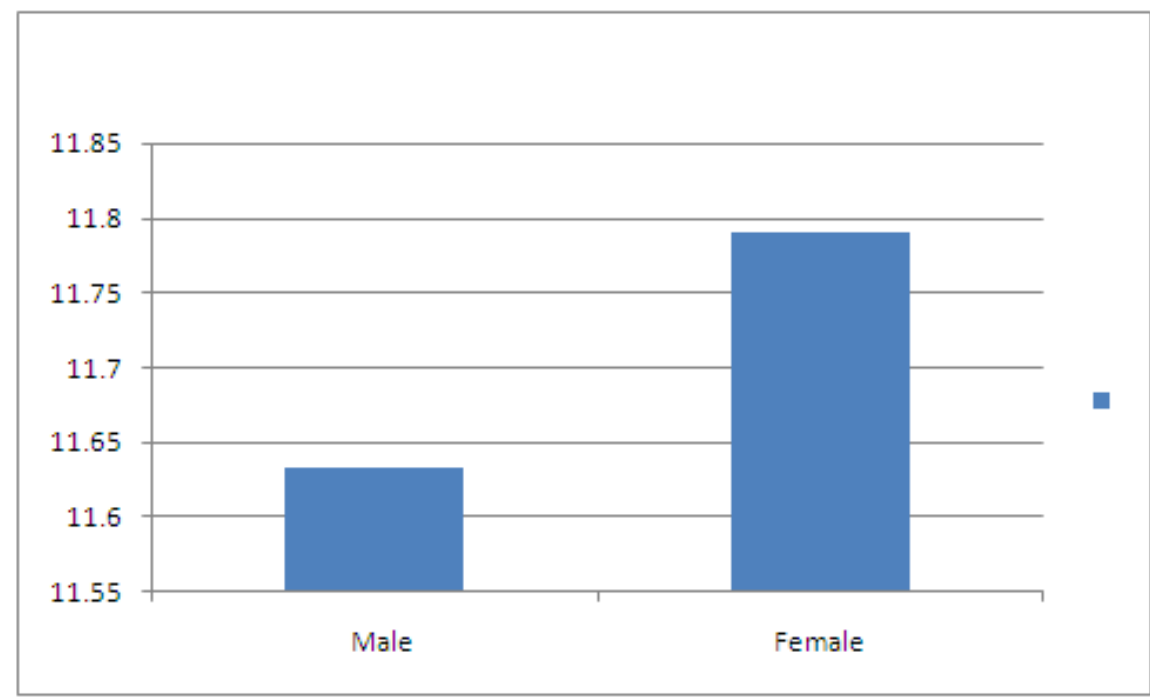

Figure 4 : Bar chart showing the Mean scores of Male and Female students in the achievement Test

Female students had higher Mean $=11.791$ while the Male students had a lower Mean $=11.633$, but the difference was not significant.

\section{Discussion of results}

This finding is related to the findings of research conducted by Tessier (2006), using Pre-Theoretic Intuitions Quiz strategy. It was found that students' achievement scores significantly improved.

The poor performance of the modified conventional method (control) group in the posttest cognitive achievement mean score when compared with the other treatment groups' mean scores may not be unconnected with the fact that the group was taught with the method that is teacher-centered. Also, it may be as a result of inadequate practice on the part of the students which is an attribute of the conventional method. That is, the conventional method does not seem to involve students with related steps and activities which they need to go through in an attempt to accomplish a given task. Modified conventional method appears to only allow students to listen passively, with little or no interaction with the teacher. Thus the relatively low cognitive achievement in modified conventional lecture method group repeats itself in this study as it was the findings of Chukwuka (2006), Ajitoni (2009), Baron (2000), Olagunju (2002), Mansaray and Ajiboye (1997), Ajiboye (1997). This is because the modified conventional method often subjects the learners to the position of passive recipient of fact handed down to him by the teacher.

\section{Educational Implications.}

The exposure of the learners to Pre-Theoretic Intuition Quiz learning strategy have been found to positively affects the enhancement of Students' environmental achievements. The findings have therefore revealed importance of using teaching strategy that are participatory and learner centered where learners are trained to take control and direct their learning processes for effective learning.

The study also revealed that there is need to incorporate in our educational system the Pre-Theoretic Intuition Quiz as strategy that could help in providing environmental cognitive achievement needed to solve various environmental problems prevalent in our surroundings. 


\section{Recommendations}

In the light of the results and discussion, the following recommendations are made:

Pre-Theoretic Intuition Quiz should be adapted as viable strategy for study environmental pollution and conservation of natural resources as they involve the students in monitoring their learning process. This is a viable teaching strategy for improving achievement needed by students in environmental concept in our primary schools.

Teaching strategies such as Pre-Theoretic Intuition Quiz that reduce the gender difference in environmental achievement as recorded in this research could be used as a basis for bringing about a reduction of anxiety in learning for both male and female pupils.

Finally, there is need to integrate into the school science curriculum, systematic ways in which practicing teachers and would-be teachers can be trained in the use of Pre-Theoretic Intuition Quiz not only for teaching environmental pollution and conservation of natural resources in basic science, but should be applied to other primary science concepts so as to produce qualified and well groomed pupils for sciences in later future.

\section{Conclusion}

This study is in line with the work of researchers who believe that strategy learning by teachers improves content learning of students (Olagunju,2002; Awolola,2009) and to develop strategies for resolving environmental problems leading to sustainable development in our country (Olagunju, 2002), thus as practicing teachers and would-be teachers were trained and became competent in the use of pre-theoretic intuition quiz and puzzle-based learning strategies in learning environmental concepts, their achievement in, environmental pollution will improved. Also, these strategies encouraged students to take control of their learning (as they are learner centered strategies) thus making students more critical in their thinking when compared with the traditional conventional teaching method which emphasized teacher activity over pupil involvement.

\section{Limitations of the Study}

Some constraints were encountered in the process of carrying out this study and may therefore limit the generalizability of the results. These constraints are stated as follows:

These include the fact that the present study was conducted in only nine schools in three local government areas of Oyo State (Ibadan North, Ibadan North East Ibadan Southeast and Akinyele). There is therefore need to replicate this study using larger population in Oyo states. Also only four selected environmental education concepts in biology were used for the study.

Cognitive style and gender were the only moderator variables used in the study. It is however possible that many other moderator variables like engagement styles, socio-economic status of students, personality traits, location of the school could put a limitation on the extent to which the result of this study could be generalized. The findings would serve as a basic foundation for future studies in the area of Pre-Theoretic Intuition Quiz strategy and its proper utilization for effective, teaching and learning of biology in our secondary schools.

\section{Contributions of the Study to Knowledge}

This study has contributed to knowledge generally in the following ways:

- Pre-theoretic intuition quiz strategy has been found to be effective in enhancing students' achievement in environmental concepts in biology as revealed by the findings in the study. This result has provided a basis for curriculum innovation in the training, retraining and in-service programmes of would-be biology teachers and those who are already in the field respectively.

- The provision of enriched learning environment and well designed pre-theoretic intuition quiz compatible instructional material as revealed in this study will improve environmental achievement, among students in teaching biology.

- pre-theoretic intuition quiz encourages concept learning and studies have shown that the two strategies exposed students to a higher thinking order needed to recognize assumptions, evaluate controversy, and scrutinize inferences in alleviating the problem of low students' learning outcomes in biology

\section{Suggestions for Further Studies}

The researcher conducted this study only in three local government areas of Oyo State. There is need to replicate this study in other local government areas in more states of Nigeria in order to give room for valid generalization.

It is hoped that samples may involve higher institutions scholars in which the independent and moderator variables may be applied to test their impact on students' learning outcomes.

It is also suggested that similar studies could be extended to other moderating variables like mental ability, social economic status and subject specialization. Other environmental concepts in biology such as ecology, 
acid rain, ozone layer depletion, greenhouse effect including other aspects of biology apart from environmental issues could be involved as this will enhance performance of our students in biological sciences.

Selected topics that could be studied include

(1) Variability, heredity and evolution

(2) Structure and physiology of organisms

(3) Cell and its environment

(4) Habitat and Population

(5) Skeletal and supporting system in animals

(6) Transport system in plants and animals

(7) Cellular respiration

(8) Feeding and nutrition in organism

(9) Alimentary system.

These are difficult concepts as indicated by Researchers Olagunju(2002), Ojo (2009) and Oduwaye (2009) including Chief examiners' reports (2002 to 2012).

\section{References}

[1]. Abimbola, (2013): The Misunderstood word in science towards a technology of perfect understanding of all. In $123^{\text {rd }}$ Inaugural lecture of University of Ilorin (p22-31) Unilorin Press.

[2]. Adegbile, J.A. (2002). Advance Organizers and Secondary School Teacher, Teaching Strategies for Nigerian schools. Unpublished PhD Thesis, University of Ibadan.

[3]. Ajiboye J.O. (1997). A Self Learning Programme, The Modified Lecture Method and Students' Cognitive and Affective Outcomes in some population Education concepts Unpublished Ph.D Thesis, University of Ibadan, Ibadan.

[4]. Ajiboye, J. O. \& Olatundun, S. A.(2010)). Impact of Some Environmental Education Outdoor Activities on Nigerian Primary School Pupils' Environmental Knowledge. Published in Applied Environmental Education \& Communication. Volume $\underline{9}$, Issue $\underline{3}$ July 2010 , pages $149-158$

[5]. Ajiboye, J.O.\& Silo, N. (2008). Enhancing Botswana Children's Environmental Knowledge, Attitude and Practices through the School Civic Club. International Journal of Environmental and Science Education 3(3) 105-114.

[6]. Ajitoni, S.O, (2009), The effect of environmental pollution on neighborhood security in Ibadan, Oyo State, Nigeria. Being paper delivered at the social studies Association National Conference, Epe Lagos Nigeria.

[7]. Atoyebi I.O., (2000): Overview of Environmental problem in Nigeria National Centre for Economic Management and Administration (NCEMA) Paper Presented at the Conference on Environment and Sustainable Development. Ibadan, 17-18 August.

[8]. Awolola,S.A, (2009); Impact of brain-based instructional strategy on students learning outcomes in senior secondary school mathematics in selected local government areas in Oyo state, Nigeria. Unpublished PhD Thesis, University of Ibadan

[9]. Azzarito, L., (2003), A Sense of Connection: Toward Social Constructivist Physical Education. Sport, Education \& Society, 8(2), 179. Retrieved May 10, 2009, from Academic Search Premier database.

[10]. Blair, K. Schwartz, D. L., Biswas, G., \& Leelawong K. (2007). Pedgogica Agent for Learning and Teaching: Teachable Agents. Educational Technology, 47(1), 56-61.

[11]. Chukwuka.C.N.(2006).The effects of moral dilemma and problem-solving strategies on secondary school students' environmental knowledge, problem- solving achievement and attitudes in selected EE concepts in biology. Unpublished PhD Thesis. University of Ibadan.

[12]. D'Avanzo C, Anderson CW, Griffith A,\& Merrill J. (2010). Thinking like a biologist: Using diagnostic questions to help students reason with biological principles. (17 January 2010; www.biodqc.org/).

[13]. DiEnno, C., \& Hilton, S. Fall, (2005). School Pupils' Knowledge, Attitudes, and Levels of Enjoyment of an Environmental Education Unit on Nonnative Plants. Journal of Environmental Education, 37(1), 13-25. Retrieved May 10, 2009, from Academic Search Premier database.

[14]. Ding, L, Chabay, R, Sherwood, B, \& Beichner, R (2006). Evaluating an electricity and magnetism assessment tool: Brief electricity and magnetism assessment Brief Electricity and Magnetism Assessment (BEMA). Phys. Rev. ST Physics Ed. Research 2, 7 pages.

[15]. Duyilemi, A.N. (2005). The jets programmes and the attitude of girls to science and technology in Nigeria. Educational Thought 4.1:32-38.

[16]. Federal Government of Nigeria (2004) Nigerian National Policy on Education (Revised) Yaba, Lagos. NERDC Press (ed).

[17]. Gbamanja S.P.T. (2001). Strategies for Teaching Waste Management to Higher Education Students. (P. Okebukola and B.B. Akpan eds) Strategies for Teaching Waste Management STAN E.E. Project Series (5). 73-85

[18]. Giancarlo, C. A., \& Facione, P. A. (2001). A look across four years at the disposition toward critical Gough A. 2002. Mutualism: A different Agenda for Environmental and Science Education. International Journal of Science Education, 24, 1201-1215.Guide for Teaching All Adults. 3rd ed. San Hand, B, \& Prain, V,(2002). Teachers implementing writing-to-learn strategies in junior Basic science; a case study, Sci. Educ. $86(6), 737-755$

[19]. Hestenes, D. (2006). Notes for a Modeling Theory of Science, Cognition and Instruction.Retrieved,October1,2010,from http://modeling.asu.edu/R\&E/Notes_on_Modeling_Theory.pdf.

[20]. Igboko, K.O. \& Ibeneme O.T,2006 Effect of some cognitive constructivism instructional Approaches on pupils Achievement and Retention in the study of Introductory Technology in Nigeria. Journal of STAN Vol.41 No 1 and 2.

[21]. Ige T.A., (2001). A Concept Mapping and Problem Solving teaching Strategies as Determinates of Achievement in secondary school Ecology: Ibadan. Journal of Educational Studies Volume 1-(1), May 2001

[22]. Ivowi, U. M. O (2000). The student's women in Physics in Nigeria. 42 ${ }^{\text {nd }}$ Annual Conference proceeding science Teacher Association of Nigeria

[23]. Jekayinfa, A.A, Yusuf, M.O., Yahaya, L.A,\& Yusuf. A., ( 2010): An overview of the philosophical, historical, political and socioeconomic factors that have impacted on the development of Universities in Nigeria. In J. Okojie, I. Oloyede, \& P.A.I. Obanya (Eds), 50 years of University education in education in Nigeria: Evolution, achievement and Future directions (pp.47-64), Ilorin \& Abuja: University of Ilorin \& National Universities Commission.

[24]. Kato Y \& Kami .C. (2001) Piaget Constructivism and Childhood Education in Japan, Prospect, XXXI(2) 161 - 173 
[25]. Kirschner, P. A., Sweller, J., and Clark, R. E. (2006). "Why minimal guidance during instruction does not work: an analysis of the failure of constructivist, discovery, problem-based, experiential, and inquiry-based teaching". Educational Psychologist 41 (2): $75-$ 86. doi:10.1207/s15326985ep4102_1

[26]. Klymkowsky, Underwood, \& Garvin-Doxas, (2010): In D'Avanzo C, Anderson CW, Griffith A, Merrill J. 2010. Thinking like a biologist: Using diagnostic questions to help students reason with biological principles.(17 January 2010

[27]. Knapp, D., \& Benton, G.M. (2006) Episodic and semantic memories of a residential environmental education program. Environmental education research, 12(2), 165- 177 http://dx.doi.org/10.1080/13504620600688906.

[28]. Maal, N. (2004). Learning via Multisensory Engagement. Association Management. Washington, DC: American Society of Association Executives.

[29]. Morribend, B (2004). Gender and Academic ability as Determinant of Students' affective and Cognitive Achievement in Environmental Education. Journal of Environmental Value Education 98 (2) pp.10-25.

[30]. Muller, D, Sharma, M., \& Reimann, P. (2008), . Raising cognitive load with linear multimedia to promote conceptual change. Science Education, 92(2), 278-296. Retrieved May 10, 2009, from Academic Search Premier database.

[31]. Ndioho.O.F.(2007): Effect of Constructivist based Instructional model on senior secondary students achievement in Biology. In U. Nzewi (ed), Science Teachers Association of Nigeria, 50 ${ }^{\text {th }}$ Annual Conference Proceedings (pp98-101) Sokoto; Heinemann Educational Books.

[32]. Nehm R \& Schonfeld IS (2010). The future of natural selection knowledge measurement: A reply to Anderson et al. 2010. Journal of Research in Science Teaching, 47, 358-362.

[33]. Nwozu,A.A. (2003). Constructivism as an Innovative Model for Science Teaching: Importance and Extent of use in Secondary schools: Journal of STAN $38(1 \& 2)$

[34]. Odom AL, Barrow LH(1995) Development and application of a two-tier diagnostic test measuring college pupils' understanding of You and enviroment after a course of instruction. Journal of Research In Science Teaching 32: 45-61.

[35]. Oduwaiye, J.O.( 2009) Impact of Computer-Assisted and Programmed Instructions on Pre-service Teachers Learning Outcomes in some Environmental Education Concept in Biology. unpublished doctoral thesis to the faculty of Education, University of Ibadan, Nigeria.

[36]. Ogunleye, B.O. (2002). Evaluation of the Environmental Aspect of the Senior Secondary School Chemistry Curriculum in Ibadan, Nigeria. Unpublished Ph.D Thesis. University of Ibadan, Ibadan.

[37]. Ojo T. A. (2008). Impact of Video CD and Audio Cassette Instructions on Students Learning Outcomes in some Environmental Education Concept in Biology. Unpublished PhD thesis to the faculty of Education, University of Ibadan, Nigeria.

[38]. Okpala, N.N \& Onocha C.O. (1995). Difficulties in Students Performance of Hierarchal Cognitive Tasks. A function of Time to Learn. UNESCO Africa. (A Six Monthly Journal of the Dakar UNESCO Regional Office.

[39]. Olagunju A.M (2002). Environment Education for sustainable Development in Nigeria. Implication for Science. Conference Proceeding of STAN on difficult concepts in STM Abeokuta.

[40]. Paul, R.W. (1990). Bloom taxonomy and critical thinking instruction. Educational Leadership, 42.36 -39.

[41]. Piaget, J: (1954). The Theory of Stages in cognitive development in Green D, Ford M. and Tamed (Ed) 1971.Measurement and Piaget. New York; McGraw till $1-11$.

[42]. Pithers, R. T., \& Soden, R.(2000).Critical thinking in education: A review. Educational Research, 42(3), 237-249. Richardson, V. (2003). Constructivist pedagogy. Teachers College Record 105(9), 1623-1640.

[43]. Popov, O. (2002): Teaching Studying, learning Natural Sciences Umea University Sweden.

[44]. Raimi, S.M.(2003). Gender Differences in Acquisition of Practical Skills, Unpublished Paper Presented at the $1^{\text {st }}$ National Conference on Science, Technology and Mathematics Education. School of Science, St. Andrew's College of Education, $17^{\text {th }}-20^{\text {th }}$, July.

[45]. Richardson, V.( 2003) Constructivist Pedagogy. Teachers College Record, 105(9), 1623-1640. Retrieved May 10, 2009, doi:10.1046/j.1467-9620.2003.00303.x

[46]. Students' Attitude and Achievement Science Education International, Tessier, J. (2006). Writing assignment in a non-major introductory ecology class. J. Coll. Sci. Teach. 35(4), 25-29.

[47]. Vygostsky, L.S.( 1978) Mind in Society .Cambridge, M.A Havard University.

[48]. WAEC,(2002): Chief Examiners' Report Nigeria WASSCE,2002 Biology, pg 136-140

[49]. WAEC,(2003): Chief Examiners' Report Nigeria WASSCE,2003 Biology, pg 130-136

[50]. WAEC,(2004): Chief Examiners Report Nigeria WASSCE,2004 Biology, pg 126-132

[51]. WAEC,2005: Chief Examiners' Report Nigeria WASSCE,2005 Biology,

[52]. WAEC,(2007): Chief Examiners' Report Nigeria WASSCE,2007 Biology,

[53]. WAEC,(2008): Chief Examiners' Report Nigeria WASSCE,2008 Biology.

[54]. WAEC,(2009). Chief Examiners' Report Nigeria WASSCE,2009 Biology.

[55]. WAEC,(2010). Chief Examiners' Report Nigeria WASSCE,2010 Biology.

[56]. WAEC,(2011). Chief Examiners' Report Nigeria WASSCE,2011 Biology.

[57]. WAEC,(2012). Chief Examiners' Report Nigeria WASSCE,2012 Biology.

[58]. Wlodkowski, R. J.(2008) Enhancing Adult Motivation to Learn: A Comprehensive Wood, W. B. \& Gentile, J. M. (2003). Teaching in a Research Context. Science 302:1510

[59]. Wright J, (1998). Chem. Ed. 75: 986-992.in Beichner, R. Testing student interpretation kinematics graphs, American . Journal of. Physics., 62, 750-762.

[60]. WWF, (2008). Education for Sustainable Societies. WWF - Brazil

[61]. Youssef, R (2004). The Effect of Teaching an Environmentally-oriented Science Unit on Students' Attitude and Achievement Science Education International, (1)pp.15-17. 